\title{
ANTESEDEN GENERASI MILENIAL UNTUK MELAKUKAN SOCIAL COMMERCE: PERAN KEPERCAYAAN
}

\author{
Kahfi Fikrianoor ${ }^{1}$, Faishal Prahatma Ganinda ${ }^{2}$, Ervilia Agustine Wiharsianti ${ }^{3}$, \\ Amir Hidayatulloh ${ }^{4}$ \\ Universitas Ahmad Dahlan, Yogyakarta \\ Email : kahfifikri@gmail.com¹, prahatmag@gmail.com², erviliaggs@gmail.com³, \\ amir.hidayatulloh@act.uad.ac.id ${ }^{4}$
}

\begin{abstract}
ABSTRAK
Penelitian ini bertujuan untuk membuktikan secara empiris apakah generasi milenial masih mempertimbangkan privasi saat melakukan social commerce. Populasi dari penelitian ini adalah pengguna media sosia. Teknik pengambilan sampel menggunakan purposive sampling, dengan kriteria (1) pengguna media sosial yang minimal dua kali sudah melakukan pembelian melalui media sosial yang dimiliki, dan (2) pengguna media sosial yang tergolong generasi milenial, yaitu rentang tahun kelahiran 1980 sampai dengan 2000. Pengumpulan data dalam penelitian ini menggunakan kuesioner yang disebarkan dengan bantuan internet, yaitu melalui google form. Penelitian ini memiliki responden berjumlah 150 responden. Alat statistik yang digunakan adalah warpPLS. Penelitian ini memperoleh hasil bahwa kepercayaan pada situs social commerce dipengaruhi oleh persepsi keefektifan kebijakan privasi dan persepsi keefektifan regulasi mandiri. Kepercayaan tehadap situs social commerce berpengaruh terhadap valensi WOM (baik positif maupun negatif), konten WOM, dan pengamatan konsumen lain. Sedangkan, niat untuk melakukan pembelian melalui medis sosial ditentukan oleh valensi WOM (baik positif maupun negatif), sedangkan konten WOM dan pengamatan konsumen lain tidak berpengaruh terhadap niat untuk melakukan pembelian melalui media sosial.
\end{abstract}

Kata Kunci : Kepercayaan, Konten WOM, Pengamatan Konsumen Lain, Social Commerce, Valensi WOM

\section{ABSTRACT}

This study aims to prove empirically whether the millennial generation is still considering privacy when conducting social commerce. The population of this study is social media users. The sampling technique in this study uses purposive sampling, with criteria (1) social media users who have made at least twice purchases through social media owned, and (2) social media users belonging to the millennial generation, namely the birth year range from 1980 to 2000 . Collecting data in this study using a questionnaire distributed with the help of the internet, namely through google form. this study has 150 responses. The statistical tool used is warpPLS. This study obtained results that trust in social commerce sites is influenced by perceptions of the effectiveness of privacy policies and perceptions of the effectiveness of selfregulation. Trust in social commerce sites affects the valence of WOM (both positive and negative), WOM content, and other consumer observations. Whereas, the intention to make purchases through social medical is determined by the WOM valence (both positive and negative), while WOM content and other consumer observations do not influence the intention to make purchases through social media.

Keywords : Trust, WOM Content, Observation of Other Consumers, Social Commerce, WOM Valence

\section{PENDAHULUAN}

Perkembangan teknologi semakin pesat sejak ditemukannya komputer. Perkembangan teknologi tidak terlepas dari perkembangan internet. Kominfo mengungkapkan 143 juta atau sekitar 54\% daro jumlah penduduk indonesia telah menggunakan internet [1]. Oleh karena itu, Indonesia adalah salah satu negara yang 
memiliki potensi untuk melakukan social commerce. Social commerce merupakan ecommerce melalui media sosial. Social commerce memanfaatkan fitur-fitur sosial yang biasanya ada pada media sosial. Sehingga, keberadaan internet pada era ini merupakan alat yang paling penting untuk menjalankan bisnis yang kompetitif [2].

Perkembangan potensi bisnis jual-beli online disebabkan salah satunya oleh kemudahan yang diberikan internet pada masyarakat modern. Perdagangan yang semula dilakukan secara tradisonal dengan tatap muka dan pembayaran tunai, berkembang menjadi penjualan melalui website atau dikenal dengan e-commerce [3]. Aktivitas jual-beli online merupakan bentuk jual- beli yang dilakukan secara non fisik, artinya pembeli dan penjual memungkinkan tidak bertatap muka secara langsung. Hal ini karena transaksi dilakukan secara elektronik.

Menurut survei APJII (Asosiasi Penyelenggara Jasa Internet Indonesia) tahun 2016, bahwa di Indonesia, internet lebih banyak digunakan dalam bisnis online, sebesar 82,2 juta orang atau $62 \%$. Lebih lanjut, suvei yang dilakukan APJII sebanyak $87,13 \%$, pengguna internet menggunakan internet untuk mengunjungi media sosial. Survei tersebut juga menemukan bahwa sebesar $49,52 \%$ pengguna media sosial berusia 19-34 tahun [4].

Penggunaan social commerce dapat memberikan manfaat ekonomi yang cukup besar. Namun, masalah privasi konsumen yang timbul dari transaksi online dan interaksi sosial pun semakin meningkat [5].

Menurut San, et al., mengungkapkan bahwa Generasi milenial di Malaysia belum siap untuk melakukan pembelian online karena kebanyakan dari mereka masih memiliki keraguan pada kepercayaan pada website saat melakukan pembelian online. Sebagian besar responden memiliki pemikiran, kepercayaan adalah faktor terpenting saat memiliki website untuk melakukan pembelian, diikuti oleh keamanan, layanan yang ditawarkan, reputasi, pengalaman pembelian, harga, kualitas produk, kegunaan dan kemudahaan saat menggunakan website [6].

Berdasarkan hasil penelitian yang dilakukan San, et al., penelitian ini ini mencoba menguji kembali model penelitian pada generasi milenial di Indonesia. Penelitian ini menggunanakn Theory of Reasoned Action atau teori minat berperilaku konsumen. Lebih lanjut [7], mengungkapkan bahwa Karakteristik atau dimensi sikap dipengaruhi oleh kepercayaan, harga dan kualitas layanan) dan norma subjektif terhadap minat beli. Sepanjang penelitian ini dibuat, penelitian ini merupakan penelitian pertama yang dilakukan pada generasi milineal di Indonesia.

\section{LANDASAN TEORI}

Situs social commerce digambarkan sebagai perdagangan dengan menggunakan jaringan dan media sosial. Fenomena social commerce berawal dari teknologi web 2.0 dan praktik media sosial. Perkembangan media sosial membuat konsumen dapat berinteraki dengan konsumen lainnya. Seiring dengan perkembangan zaman, media sosial diguaan sebagai salah satu alat untuk melakukan perdagangan [8]. Konten informasi pada social commerce dapat bersumber dari konten degenerasi yang berbentuk ulasan, peringkat, rekomendasi, posting dan lain sebagainya, atau konten yang dibuat oleh perusahaan. Namun, interaksi sosial menimbulkan masalah privasi, 
antara lain data dapat disalahgunakan. Data yang diakses secara tidak sah dapat mengakibatkan kesalahan informasi pribadi dan akses yang tidak terkendali [9].

\section{Jaminan Privasi Berbasis Institusi}

Privasi dan keamanan merupakan inti dari kualitas dari suatu social commerce [10]. Masyarakat menggunakan social commerce karena masyarakat menganggap bahwa privasi saat menggunakan social commerce lebih terlindungi dibandingkan ketika menggunakan e-commerce atau transaksi offline. Hal ini disebabkan karena masyarakat menganggap fitur baru yang disediakan social commerce lebih memperhatikan privasi. Menurut Preibusch et al., kekhawatiran masyarakat dalam privasi semakin meningkat saat melakukan transaksi dengan menggunakan teknologi yang lebih canggih [11].

Penelitian sebelumnya, Wang \& Herrando memperkenalkan privasi berbasis jaminan institusi, yang mengacu pada intervensi yang dilakukan perusahaan untuk meyakinkan konsumen bahwa perusahaan telah berusaha untuk melindungi informasi pribadi konsumen. Oleh karena itu, adanya jaminan tersebut akan memengaruhi masyarakat saat mengambil keputusan yang terkait dengan pengungkapan informasi pribadi. Oleh sebab itu, konsumen merasa aman dalam transaksi online, serta masyarakat memiliki cenderung mempercayai situs social commerce.

\section{Kepercayaan Berbasis Institusi}

Kepercayaan berperan penting dalam perdagangan online. Menurut Chen \& Shen, pembeli akan mempetimbangkan ketidakpastian dan risiko saat melakukan pembelian Online [12]. Kepercayaan dipandang sebagai interpersonal nilai, dengan alasan bahwa kepercayaan konsumen Tiongkok terhadap anggota mempengaruhi niat untuk social commerce. Kepercayaan berbasis institusi didefinisikan sebagai persepsi individu terhadap lingkungan institusional. Lebih lanjut, Harrison McKnight et al., 2002) menekankan bahwa hukum perlindungan yang diberikan oleh suatu institusi dapat membuat pengguna percaya terhadap institusi tersebut, dan akhirnya akan mendorong pengguna untuk melakukan pembelian [13].

\section{Interaksi Sosial Pada Social Commerce}

Sosial commerce yang semakin terkenal di kalangan masyarakat, para akademisi dan institusi lebih memperhatikan perilaku konsumen, dan pengaruhnya terhadap keputusan pembelian [14]. Interaksi sosial yang terdapat pada social commerce memiliki dua bentuk yaitu dari mulut ke mulut dan dengan mengamati pembeli lainnya. Bentuk mulut ke mulut (WOM) memberikan peran aktif kepada pembeli. Pembeli berpartisipasi dan berkomunikasi pada tampilan perdagangan sosial dengan cara memposting rekomendasi, berbagi pengalaman, memberi peringkat produk, dan lain sebagainya.

Bentuk kedua dari interaksi yang ada pada social commerce adalah dengan mengamati pembeli lainnya. Biasanya pengguna yang seperti ini merupakan pengguna pasif. Pengguna tersebut akan membaca, dan mempertimbangkan konten yang dihasilkan dan dibagikan oleh pengguna lain. Pengguna tersebut mengamati, mengumpulkan pengetahuan, dan belajar dari perilaku perilaku konsumen lain. Masyarakat memiliki kecenderungan untuk mengamati perilaku dan keputusan pembelian konsumen lain. Hal ini dapat dijelaskan dengan teori belajar observasional 
[12]. Menurut Bandura dan McClelland, teori belajar observasional mengacu pada proses pembelajaran melalui pengamatan perilaku orang lain [15]. Proses pengamatan tersebut dapat memengaruhi perilaku individu dalam banyak hal, baik dengan konsekuensi positif maupun konsekuensi negatif. Sehingga, individu akan mendapatkan pengetahuan dan pembelajaran dengan mengamati perilaku orang lain melalui konten yang dibuat pengguna. Oleh sebab itu, interaksi sosial bentuk pengamatan dianggap tindakan pasif individu

\section{Pengaruh Jaminan Privasi Berbasis Institusi Terhadap Kepercayaan}

Tolak ukur jaminan privasi berbasis institusi yang digunakan dalam penelititain ini mencakup persepsi keefektifan kebijakan privasi dan persepsi efektivitas pengaturan mandiri industry. Persepsi efektivitas kebijakan privasi didefinisikan sebagai tingkat kepercayaan konsumen mengenai pemberitahuan privasi yang disajikan pada laman online yang dapat memberikan informasi yang akurat dan dapat diandalkan mengenai praktik privasi informasi perusahaan [16]. Berbicara mengenai e-commerce, konsumen akan mengisi data pribadi ketika melakukan pendaftaran sebagai anggota maupun saat melakukan pembelian. Oleh karena itu, adanya kebijakan privasi, konsumen akan merasa aman walaupun telah mengisi informasi pribadi secara online. Kebijakan privasi dapat disebut sebagai mekanisme untuk menjaga informasi konsumen agar tetap terlindungi.

Beberapa situs social commerce mungkin memberikan wewenang kepada pihak ketiga untuk mengakses informasi pribadi konsumennya. Oleh karena itu, konsumen enggan memberikan informasi pribadi ketika konsumen merasa tidak informasi pribadinya tidak aman. Kekhawatiran konsumen dapat menghasilkan tindakan negatif anggota online, seperti menjadi kurang bersedia untuk mengeluarkan informasi pribadi, mengurangi niat untuk menggunakan layanan online dan ketidakpercayaan terhadap situs web [17].

Laman social commerce tidak hanya meningkatkan transparansi dan menjelaskan informasi penggunaan, peran pengguna, kontrol dan izin pengguna, tetapi juga menyediakan penjelasan privasi selama proses pembelian. Hal ini dilakukan untuk mengurangi masalah privasi konsumen [18]. Sehingga, dapat diketahui bahwa hipotesis pertama penelitian ini adalah:

Efektifitas regulasi mandiri pada industri merupakan bentuk dari jaminan privasi industri. Efektivitas regulasi mandiri didefinisikan sebagai tingkat kepercayaan konsumen bahwa kelompok regulasi mandiri tersebut dapat membantu melindungi konsumen. Kelompok regulasi mandiri berasal dari kelompok industri dan lembaga sertifikasi, Kelompok regulasi mandiri meliputi pihak ketiga seperti bank, serikat konsumen, atau perusahaan layanan teknologi dan informasi. Berdasarkan teori kepercayaan, pihak ketiga berfungsi sebagai sumber penyalur kepercayaan, yang membantu perantara amanat untuk memfasilitasi pengawas jika ada hubungan dekat antara perantara amanat dengan pengawas [19].

\section{Pengaruh Kepercayaan Berbasis Institusi Pada Interaksi Sosial}

Social commerce adalah lingkungan belanja online, tempat interaksi sosial dan pertukaran informasi [20]. Secara umum, kepercayaan dapat dibangun dengan cara holistik dan timbal balik antara pengguna dan perusahaan yang terkait dengan iklan. 
Kepercayaan terhadap laman social commerce dapat ditingkatkan melalui WOM (word of mouth). WOM dihasilkan melalui interaktivitas dan dukungan sosial dalam website.

\section{Komunikasi WOM(Word Of Mouth)}

Valensi WOM diasumsikan memengaruhi minat pembelian konsumen. Valensi WOM yang positif akan membantu penjual untuk meningkatkan penjualannya, tidak hanya itu hal tersebut dapat membantu konsumen untuk mendapatkan rekomendasi barang yang bagus dan mendukung keputusan pembelian [21]. Pada umumnya konsumen akan menilai valensi WOM yang positif adalah kepuasan terhadap suatu barang, sementara valensi WOM yang negatif cenderung menekankan bahwa adanya kelemahan dalam suatu produk. Konsumen lebih menekankan kepada negatif WOM sebagai penimbang landasan dalam mengambil keputusan. Kepuasan dan kekecewaan dapat mempengaruhi individu untuk melakukan komunikasi WOM yang negatif, hal tersebut didukung oleh penelitian yang dilakukan [22] yang menyatakan bahwa word of mouth berpengaruh terhadap keputusan pembelian.

\section{Pengamatan Koumsumen Sebelum Melakukan Pembelian}

Perilaku konsumen dalam melakukan transaksi online mengungkapkan bahwa informasi yang didapat oleh konsumen sebelumnya dakan dikaitkan dengan pengambilan keputusan yang diambil oleh konsumen dalamm melakukan transaksi [23].

\section{Niat Pembelian dan Perilaku Aktual Pembelian}

Pada situs social commerce, konsumen menghabiskan waktu untuk mencari informasi dan mengevaluasi pilihan yang mungkin dapat diambil. Setelah memperoleh informasi yang memadai dan mengevaluasi dari sumber informasi, konsumen akan menentukan faktor penentu yang digunakan untuk membandingkan dengan pilihan lain dan membuat keputusan berdasarkan apa yang mereka pahami [15].

\section{METODOLOGI PENELITIAN}

Penelitian ini memiliki populasi dari pengguna media sosial. Teknik pengambilan sampel dalam penelitian ini menggunakan purposive sampling, dengan kriteria (1) pengguna media sosial yang sudah melakukan pembelian melalui media sosial yang dimiliki, minimal dua kali pembelian, (2) pengguna media sosial yang tergolong generasi milenial, yaitu rentang kelahiran 1980 sampai dengan 2000 [24]. Pengumpulan data dalam penelitian ini kuesioner yang disebarkan dengan komputer, dalam hal ini memanfaatkan fasilitas google form.

Perspektif keefektifan kebijakan privasi didefinisikan sebagai tingkat kepercayaan konsumen terhadap pemberitahuan privasi yang diunggah online yang memberikan informasi secara akurat dan andal mengenai praktik inforormasi privasi perusahaan. Perspektif keefektifan kebijakan privasi diukur dengan mengggunakan tiga item pertanyaan yang diadopsi [15] dan menggunakan skala likert lima poin, (1) sangat tidak setuju, (2) tidak setuju, (3) ragu-ragu, (4) setuju, dan (5) sangat setuju.

Perspektif keefektifan regulasi industri mandiri didefisikan sebagai tingkat kepercayaan konsumen bahwa kelompok indusrtri pemolisan mandiri dan agen sertifikasi dapat membantu konsumen dalam melindung privasi online. Pengukuran Perspektif keefektifan regulasi industri mandiri menggunakan dua item pertanyaan 
yang diadopsi [15] dan menggunakan skala likert lima poin, (1) sangat tidak setuju, (2) tidak setuju, (3) ragu-ragu, (4) setuju, dan (5) sangat setuju.

Kepercayaan berbasis institusi adalah persepsi individu mengenai lingkungan kelembagaan. Kepercayaan berbasis institusi diukur dengan tiga item pertanyaan yang diadopsi [15] dan menggunakan skala likert lima poin, (1) sangat tidak setuju, (2) tidak setuju, (3) ragu-ragu, (4) setuju, dan (5) sangat setuju.

Valensi WOM adalah adalah preferensi dilakukan dalam informasi WOM sering diukur sebagai positif, negatif maupun dengan peringkat pengguna. Valensi WOM positif diukur dengan empat item pertanyaan, sedangan valensi WOM negatif diukur dengan item pertanyaan yang diadopsi [15] dan menggunakan skala likert lima poin, (1) sangat tidak setuju, (2) tidak setuju, (3) ragu-ragu, (4) setuju, dan (5) sangat setuju.

Konten WOM adalah Kualitas dan variasi informasi yang dibagikan melalui website (Goyette et al., 2010). Konten WOM diukur dengan dua item pertanyaan yang diadopsi (Wang \& Herrando, 2019b) dan menggunakan skala likert lima poin, (1) sangat tidak setuju, (2) tidak setuju, (3) ragu-ragu, (4) setuju, dan (5) sangat setuju.

Pengamatan pembelian konsumen lain adalah tindakan mengamati individu sebelum membuat keputusan pembelian [12]. Pengamatan pembelian konsumen lain diukur dengan tiga item pertanyaan yang diadopsi [15] dan menggunakan skala likert lima poin, (1) sangat tidak setuju, (2) tidak setuju, (3) ragu-ragu, (4) setuju, dan (5) sangat setuju.

Niat pembelian adalah kesediaan individu untuk membeli di situs social commerce. Niat pembelian diukur dengan tiga item pertanyaan yang diadopsi [15] menggunakan skala likert lima poin, (1) sangat tidak setuju, (2) tidak setuju, (3) ragu-ragu, (4) setuju, dan (5) sangat setuju.

Hipotesis dalam penelitian ini diuji dengan menggunakan WarpPLS. PLS sebagai persamaan struktural (SEM) berbasis varian yang secara simultan dapat melakukan uji model pengukuran dan uji model struktural. Model pengukuran digunakan untuk uji validitas dan uji reliabilitas. Sedangkan, model struktural digunakan untuk pengujian hipotesis dengan model prediksi (kausalitas).

\section{Hasil Penelitian dan Pembahasan}

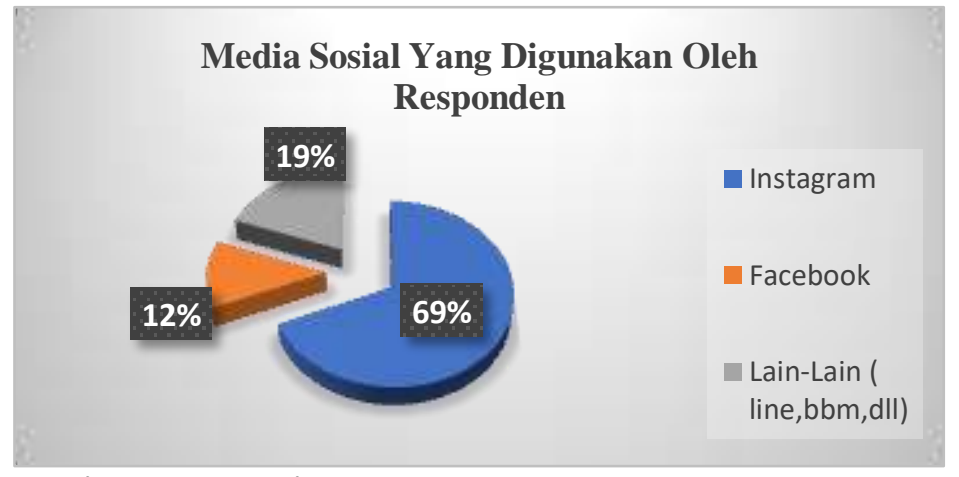

Sumber: Data penelitian, 2019

Gambar 1. Media Sosial Yang Sering Digunakan 
Media sosial yang digunakan untuk pembelian oleh responden didominasi oleh Instagram, sebesar 69\%. Sedangkan sebesar 12\%, responden menggunakan facebook untuk melakukan pembelian, serta 19\% menggunakan media lainnya (seperti line, BBM, dan sebagainya). Lebih lanjut, data mengenai penggunakan media sosial disajikan pada gambar 1 .

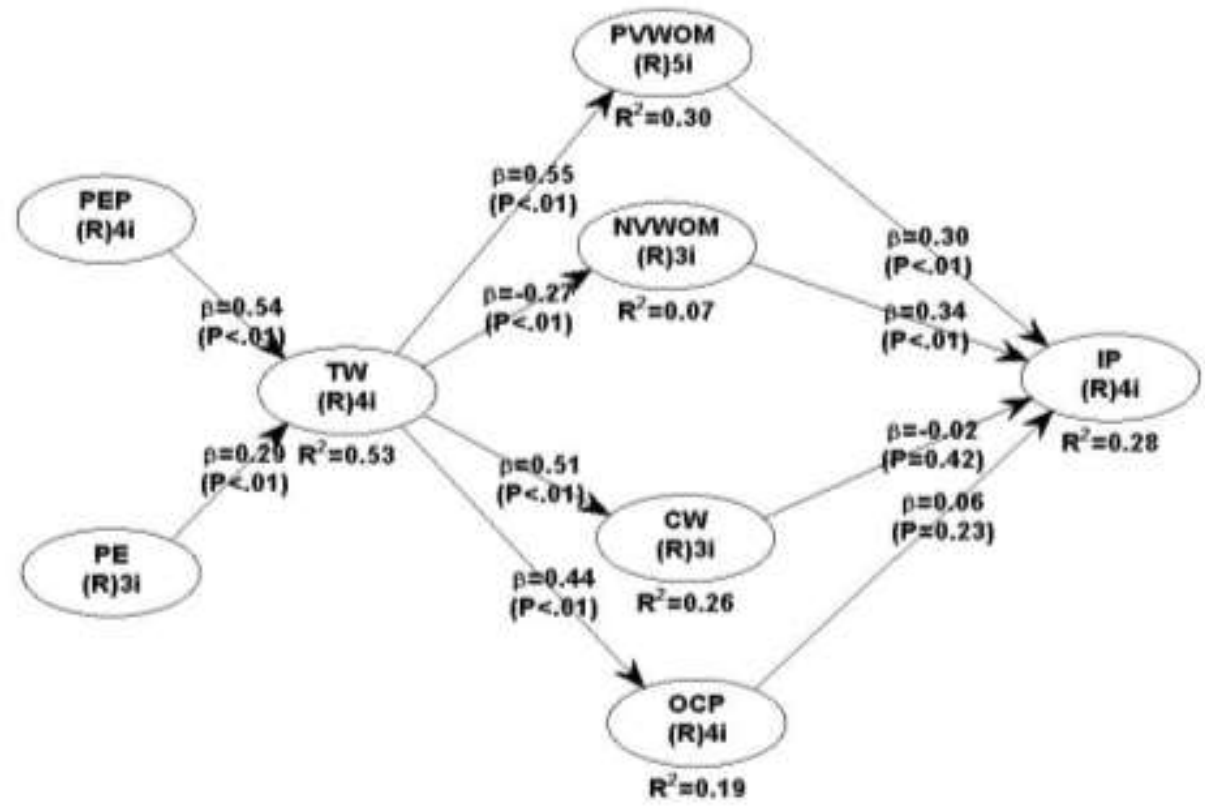

Sumber: Data penelitian, 2019

\section{Gambar 2. Full Model SEM}

Kepercayaan terhadap laman social commerce memiliki nilai $R$-square sebesar 0,53 . Hal ini berarti bahwa variasi perubahan variabel kepercayaan pada laman social commece dapat dijelaskan oleh konstruk persepsi efektifan kebijakan privasi dan persepsi keefektifan regulasi mandiri sebesar $53 \%$, sedangkan sisanya dijelaskan oleh variabel lain diluar model penelitian.

Positif WOM memiliki nilai R-square sebesar 0,30. Hal ini berarti bahwa variasi perubahan variabel positif WOM dapat dijelaskan oleh variabel kepercayaan pada laman social commerce sebesar $30 \%$, sedangkan sisanya dijelaskan oleh variabel lain diluar model penelitian.

Negatif WOM memiliki nilai R-square sebesar 0,07. Hal ini berarti bahwa variasi perubahan variabel negatif WOM dapat dijelaskan oleh variabel konstruk kepercayaan terhadap laman social commerce sebesar 7\%, sedangkan sisanya dijelaskan oleh variabel lain diluar model penelitian.

Konten WOM memiliki nilai R-square sebesar 0,26. Hal ini berarti bahwa variasi perubahan variabel konten WOM dapat dijelaskan oleh variabel konstruk kepercayaan terhadap laman social commerce sebesar $26 \%$, sedangkan sisanya dijelaskan oleh variabel lain diluar model penelitian.

Pengamatan pembelian konsumen lain memiliki nilai R-square sebesar 0,19. Hal ini berarti bahwa variasi perubahan variabel pengamatan pembelian konsumen lain dapat dijelaskan oleh variabel konstruk kepercayaan terhadap laman social commerce sebesar $19 \%$, sedangkan sisanya dijelaskan oleh variabel lain diluar model penelitian. 
Niat untuk melakukan pembelian melalui media sosial memiliki R-square sebesar 0,28 . Hal ini berarti bahwa variasi perubahan variabel niat untuk melakukan pembelian melalui media sosial dapat dijelaskan oleh konstruk WOM positif, WOM negatif, konten WOM, dan pengamatan pembelian konsumen lain sebesar $28 \%$, sedangkan sisanya dijelaskan oleh variabel lain diluar model penelitian.

Gambar 2 juga menyajikan nilai koefisien path atau outer model. Gambar 2 menunjukkan bahwa perspektif keefektivan kebijakan privasi berpengaruh positif terhadap kepercayan pada situs social commerce. Hal ini ditunjukkan dengan nilai signifikansi $(<0.01)$ yang lebih kecil dari 0,05 dan ditunjukkan dengan nilai koefiesnsi 0,54 . Atau dengan kata lain, hipotesis pertama $(\mathrm{H} 1)$ penelitian ini terdukung. Oleh karena itu, perspektif kebijakan privasi mempengaruhi kepercayaan konsumen dalam melakukan social commerce yang ditunjukan dengan tingkat kepercayaan konsumen terhadap laman online tersebut yang menjamin data-data pribadi pelanggannya secara aman.. Hasil ini didukung oleh hasil penelitian terdahulu yang menyatakan bahwa masalah privasi konsumen dapat dikurangi dengan penyediaan layanan yang dapat menjamin dan menjelaskan bahwa data diri konsumen dapat dijaga secara aman. Hasil ini pula didukung oleh penelitian yang menyatakan bahwa kepercayaan pada laman social commerce, termasuk didalamnya mengenai kepercayaan terhadap terjaminnya informasi pribadi pelanggan-pelanggan yang tergabung dalam laman social commerce tersebut [20].

Perspektif keefektifan regulasi industri mandiri berpengaruh positif terhadap kepercayaan pada situs social commerce. Hal ini ditunjukan dengan nilai signifikansi $(<0,01)$ yang lebih kecil dari 0.05 dan ditunjukan dengan nilai koefisien 0,29 . Oleh karena itu perspektif regulasi industri mandiri mempengaruhi kepercayaan pada situs social commerce, sejauh mana si pemberi layanan social commerce tersebut dapat memberikan rasa aman berupa aturan atau regulasi terhadap data privasi pengguna social commerce, sehingga pengguna social commerce merasa privasinya terlindungi oleh adanya regulasi tersebut. Atau dengan kata lain, hipotesis kedua $(\mathrm{H} 2)$ penelitian ini terdukung. Hasil ini didukung oleh penelitian, mengatakan bahwa regulasi mandiri merupakan alat penting untuk mengatur bisnis yang berubah dengan cepat dalam ekonomi dan informasi. Dengan program regulasi mandiri yang kuat dapat mendorong inovasi sambil melindungi privasi.

Kepercayaan terhadap situs social commerce berpengaruh positif terhadap WOM Positif. Hal ini dapat ditunjukan dengan nilai signifikansi $(<0,01)$ yang lebih kecil dari 0,05 dan ditunjukan dengan nilai koefisien 0,55 . Oleh karena itu kepercayaan terhadap situs social commerce berpengruh positif pada WOM positif. Atau dengan kata lain hipotesis ketiga a $(\mathrm{H} 3 \mathrm{a})$ penelitian ini terdukung. Hal ini karena pengguna social commerce tersebut percaya bahwa social commerce yang digunakan dapat melindungi privasi konsumen, dan akhirnya konsumen tersebut akan merekomendasikan social commerce tersebut kepada konsumen lain. Pelanggan yang telah memiliki rasa percaya terhadap situs social commerce memiliki niat untuk membeli produk atau layanan vendor, dan bahkan, merekomendasikan vendor kepada konsumen lain yang lain (Word Of Mouth). 
Kepercayaan terhadap situs social commerce berpengaruh negatif terhadap WOM negatif. Hal ini dapat ditunjukan dengan nilai signifikansi $(<0,01)$ yang kebih kecil dari 0,05 dan ditunjukan dengan nilai koefisien -0,27. Oleh karena itu kepercayaan terhadap situs social commerce berpengaruh negatif terhadap WOM negatif. Atau dengan kata lain hipotesis ketiga $b(\mathrm{H} 3 b)$ terdukung. Menurut penelitian yang dikemukakan [14], informasi buruk tentang situs social commerce tidak berdampak pada kepercayaan pengguna situs yang sudah mempercayai situs social commerce tersebut.

Kepercayaan terhadap situs social commerce berpengaruh positif terhadap konten WOM. Hal ini ditunjukkan dengan nilai signifikansi $(<0,01)$ yang lebih kecil dari 0,05 dan ditunjukkan dengan nilai koefisien 0,51. Atau dengan kata lain hipotesis tiga $c$ (H3c) penelitian ini terdukung. Oleh karena itu kepercayaan terhadap situs social commerce berpengaruh positif terhadap valensi WOM karena jika seorang konsumen telah percaya jika produk dan pelayanan di suatu social commerce tersebut baik maka, konsumen tersebut akan percaya jika situs social commerce tersebut merupakan situs terpercaya, hasil ini didukung oleh penelitian.

Kepercayaan terhadap social commerce berpengaruh positif terhadap pengamatan pembelian konsumen. Hal ini ditunjukkan dengan nilai signifikansi $(<0,01)$ yang lebih kecil dari 0,05 dan ditunjukkan dengan nilai koefisien 0,44. Atau dengan kata lain hipotesis keempat $(\mathrm{H} 4)$ penelitian ini terdukung. Oleh karena itu kepercayaan terhadap situs social commerce berpengaruh positif terhadap pengamatan pembelian konsumen karena konsumen sebelum membeli barang di situs social commerce, konsumen terlebih dahulu akan membaca review atau ulasan dari beberapa barang yang akan dibeli, sehingga dari ulasan tersebut akan mempengaruhi konsumen tersebut terhadap kepercayaan pada situs social commerce.

WOM Positif berpengaruh positif terhadap minat pembelian. Hal ini ditunjukan dengan nilai signifikansi $(<0,01)$ yang lebih kecil dari 0,05 dan ditunjukan dengan nilai koefisien 0,30 . Oleh karena itu positif WOM memiliki pengaruh positif terhadap niat untu melakukan pembelian. Atau dengan kata lain, hipotesis kelima a (H5a) terdukung. Hal ini karena jika konsumen mendengar tanggapan mengenai kepuasan terhadap layanan, produk atau bahkan jasa dari beberapa konsumen lain mengenai suatu situs social commerce, maka konsumen tersebut akan terpengaruhi sehingga berminat untuk melakukan social commerce pada situs tersebut. Hasil ini didukung penelitian terdahulu, bahwa word of mouth positif yang membawa pesan kepuasan terhadap produk/ jasa, dapat meningkatkan minat beli seseorang bahwa pengambilan keputusan untuk menggunakan sebuah produk atau jasa. Sehingga secara umum dapat disimpulkan bahwa word of mouth atau berita dari mulut ke mulut mampu mempengaruhi minat atau keputusan beli seseorang.

WOM negatif berpengaruh positif tehadap minat pembelian. Hal ini ditunjukan dengan nilai signifikansi $(<0,01)$ yang lebih kecil dari 0,05 dan ditunjukan dengan nilai koefisien sebesar 0,34 . Oleh karena itu negatif WOM mempengaruhi secara positif terhadap minat pembelian. Atau dengan kata lain, hipotesis kelima $b(\mathrm{H} 5 \mathrm{~b})$ penelitian ini terdukung. Adanya tanggapan mengenai ketidakpuasan terhadap layanan pada 
situs social commerce dapat mempengaruhi minat pelanggan, sehingga pelanggan merasa enggan untuk menggunakan layanan social commerce tersebut.

Konten WOM tidak berpengaruh terhadap minat pembelian. Hal ini dapat dilihat dari nlai signifikansi $(0,42)$ yang lebih besar dari 0,05 dan ditunjukan dengan nilai koefisien sebesar -0,02. Atau dengan kata lain hipotesis keenam (H6) penelitian ini tidak terdukung. Oleh karena itu konten WOM tidak mempengaruhi niat individu untuk melakukan pembelian. Hal ini karena konsumen yang memiliki niat pembelian secara pribadi maka konsumen tersebut tidak akan memperhatikan dan tidak akan menghiraukan konten WOM.

Pengamatan pembelian konsumen lain tidak berpengaruh terhadap minat pembelian. Hal ini dapat dilihat dari nilai signifikansi $(0,23)$ yang lebih besar dari 0,05 dan ditunjukan dengan nilai koefisien sebesar 0,06. Atau dengan kata lain, hipotesis ketujuh penelitian ini tidak terdukung. Oleh karena itu pengamatan pembelian konsumen tidak mempengaruhi niat pembelian. Hal ini terjadi ketika konsumen memiliki keinginan untuk melakukan pembelian melalui social commerce maka konsumen tersebut tidak akan melihat ulasan atau review produk dari konsumenkonsumen yang lainnya.

\section{KESIMPULAN DAN SARAN}

Setelah melakukan penelitian mengenai pertimbangan privasi pada generasi milenial, peneliti dapat menarik kesimpulan bahwa :

1. Perspektif keefektifan kebijakan privasi berpengaruh positif terhadap kepercayaan konsumen pada situs social commerce yang digunakan.

2. Perspektif keefektifan pengaturan industri mandiri berpengaruh positif terhadap kepercayaan konsumen pada situs social commerce yang digunakan.

3. Kepercayaan pada situs social commerce berpengaruh positif terhadap valensi WOM positif

4. Kepercayaan pada situs social commerce berpengaruh negatif terhadap valensi WOM negatif

5. Kepercayaan pada situs social commerce berpengaruh positif terhadap konten WOM

6. Kepercayaan pada situs social commerce berpengaruh positif terhadap pengamatan konsumen lain

7. Valensi WOM positif berpengaruh positif terhadap niat untuk melakukan pembelian secara online

8. Valensi WOM negative berpengaruh positif terhadap niat untuk melakukan pembelian secara online

9. Konten WOM tidak berpengaruh terhadap niat untuk melakukan pembelian online.

10. Pengamatan kosumen lain tidak berpengaruh terhadap niat untuk melakukan pembelian secara online. 


\section{DAFTAR PUSTAKA}

[1] Kominfo. (2018). kementerian kominfo sebut pengguna internet indonesia capai 54 persen.

[2] Wahyudi, M., Mukrodi, M., Harras, H., \& Sugiarti, E. (2020). Wirausaha Muda Mandiri: Learning, Sharing \& Practice. SCIENTIFIC JOURNAL OF REFLECTION: Economic, Accounting, Management and Business, 3(1), 101110.

[3] Agustina, D. (2017). Fitur Social Commerce Dalam Website E-Commerce Di Indonesia. Jurnal Informatika Mulawarman, 12(1), 25-29.

[4] APJII. (2018). No Title. Retrieved from https://apjii.or.id/downfile/file/BULETINAPJIIEDISI23April2018.pdf

[5] Wang, Y., \& Herrando, C. (2019a). Does privacy assurance on social commerce sites matter to millennials? International Journal of Information Management, 44(October 2018), 164-177. https://doi.org/10.1016/j.ijinfomgt.2018.10.016

[6] San, L. Y., Omar, A., \& Thurasamy, R. (2015). Online Purchase: A Study of Generation $Y$ in Malaysia. International Journal of Business and Management, 10(6), 1-7. https://doi.org/10.5539/ijbm.v10n6p298

[7] Serafino, J. (2018). New Guidelines Redefine Birth Years for Millennials, Gen-X, and "Post-Millennials." Retrieved February 11, 2019, from http://mentalfloss.com/article/533632/new-guidelines-redefine-birth-yearsmillennials-gen- $X$-and-post-millennials

[8] Lin, X., Li, Y., \& Wang, X. (2016). Social commerce research: Definition , research themes and the trends. International Journal of Information Management. https://doi.org/10.1016/j.jijnfomgt.2016.06.006

[9] Bergström, A. (2015). Online privacy concerns: A broad approach to understanding the concerns of different groups for different uses. Computers in Human Behavior, 53, 419-426. https://doi.org/10.1016/j.chb.2015.07.025

[10] Mamonov, S., \& Benbunan-Fich, R. (2017). Exploring factors affecting social ecommerce service adoption: The case of Facebook Gifts. International Journal of Information Management, 37(6), 590-600. https://doi.org/10.1016/j.ijinfomgt.2017.05.005

[11] Preibusch, S., Peetz, T., Acar, G., \& Berendt, B. (2016). Electronic Commerce Research and Applications Shopping for privacy: Purchase details leaked to PayPal q, 15, 52-64. https://doi.org/10.1016/j.elerap.2015.11.004

[12] Chen, J., \& Shen, X. (2015a). Consumers' decisions in social commerce context: An empirical investigation. Decision Support Systems, 79, 55-64. https://doi.org/10.1016/j.dss.2015.07.012

[13] Harrison McKnight, D., Choudhury, V., \& Kacmar, C. (2002). The impact of initial consumer trust on intentions to transact with a web site: A trust building model. Journal of Strategic Information Systems, 11(3-4), 297-323. https://doi.org/10.1016/S0963-8687(02)00020-3

[14] Cheung, C. M. K., Xiao, B. S., \& Liu, I. L. B. (2014). Do actions speak louder than voices? the signaling role of social information cues in influencing consumer purchase decisions. Decision Support Systems, 65(C), 50-58. 
https://doi.org/10.1016/j.dss.2014.05.002

[15] Wang, Y., \& Herrando, C. (2019b). International Journal of Information Management Does privacy assurance on social commerce sites matter to millennials? International Journal of Information Management, 44(December 2017), 164-177. https://doi.org/10.1016/j.ijinfomgt.2018.10.016

[16] Sari, S. P. . (2020). STRATEGI MENINGKATKAN PENJUALAN DI ERA DIGITAL. SCIENTIFIC JOURNAL OF REFLECTION : Economic, Accounting, Management and Business, 3(3), 291-300

[17] Bansal, G., Mariam, F., \& Gefen, D. (2015). Information \& Management Do context and personality matter? Trust and privacy concerns in disclosing private information online. Information \& Management 53 (2016) 1-21, 53, 1-21.

[18] Huang, Z., \& Benyoucef, M. (2013). From e-commerce to social commerce: A close look at design features. Electronic Commerce Research and Applications, 12(4), 246-259.

[19] Farhat, L. (2020). KEPUTUSAN PEMBELIAN ONLINE. SCIENTIFIC JOURNAL OF REFLECTION : Economic, Accounting, Management and Business, 3(1), 5160

[20] Chow, W. S., \& Shi, S. (2018). CS4106 Dynamic and Static Program Analysis for Software Security (2017/18 Q2) -CS4106 Dynamic and Static Program Analysis for Soft.... Retrieved from https://brightspace.tudelft.nl/d21/le/content/49651/printsyllabus/PrintSyllabus

[21] Mathodah, S. (2019). PENGARUH KUALITAS PELAYANAN DRIVER OJEK ONLINE TERHADAP KEPUASAN KONSUMEN PADA GOJEK AREA TANGERANG SELATAN. SCIENTIFIC JOURNAL OF REFLECTION: Economic, Accounting, Management and Business, 2(3), 271-280.

[22] Mahendrayasa, A. C. (2014). Pengaruh Word Of Mouth Terhadap Minat Beli Serta Dampaknya Pada Keputusan Pembelian. Universitas Brawijaya.

[23] Fadillah, M., \& Anismadiyah, V. (2019). DAMPAK PEMBELIAN ONLINE TERHADAP OMZET PENJUALAN BUSANA WANITA DI BLOK B LANTAI LG LOS A-D, PASAR TANAH ABANG. SCIENTIFIC JOURNAL OF REFLECTION : Economic, Accounting, Management and Business, 2(4), 391-40

[24] Hartono, J., \& Abdillah, W. (2014). . Konsep dan Aplikasi (Partial Least Square) untuk Penelitian Empiris (1st ed.). Yogyakarta: BPFE UGM. 